\title{
Akdeniz Bölgesi Süs Bitkisi Yetiştiricilik Alanlarında Krizantem (Chrysanthemum morifolium Ramat.) Bitkilerinde Bulunan Viroidlerin Araştırılması
}

\author{
Gülbahar ARIKAN ${ }^{1}$, Büşra FIDANCI AVCI ${ }^{1}$, Orhan BOZAN ${ }^{1 *}$, Nüket \\ ÖNELGE ${ }^{1}$
}

\begin{abstract}
ÖZ
Dünyada süs bitkilerinde virüs ve viroid etmenlerinin neden olduğu birçok hastalık bulunmaktadır. Günümüze kadar dünyada krizantemlere spesifik önemli ekonomik kayılara neden olan 2 adet viroid cinsi tespit edilmiştir. Bunlar Avsunviroidae familyasından olan Chrysanthemum chlorotic mottle viroid (CChMVd)'i ve Pospiviroidae familyasından Chrysanthemum stunt viroid (CSVd) dir. $\mathrm{Bu}$ çalışmada Akdeniz Bölgesinde Adana, Mersin ve Antalya illerinden toplanan 56 krizantem örneği RT-PCR yöntemi ile taranarak 2 farklı viroidin bulaşıklığ sonucunda krizantem bitkilerinde CSVd varlığ 1 tespit edilmiştir. Çalışmada karantina etmeni olan CChMVd 'i toplanan hiçbir izolatta tespit edilememiştir. CSVd etmeni mekanik olarak etrog citron ve krizantem bitkilerine aktarılmış, bu bitkiler üzerinde genel bir bodurluk yaprak küçüklüğü ve beneklenmesi belirtilerini geliştirmiştir.
\end{abstract}

Anahtar Kelimeler: Krizantem, CSVd, CChMVd, Viroid

\section{Investigation of Viroids in Chrysanthemum (Chrysanthemum morifolium Ramat.) Plants in Ornamental Plant Cultivation Areas of Mediterranean Region}

\begin{abstract}
There are many diseases caused by viruses and viroid factors in ornamental plants in the world. To date, 2 viroid species have been identified in the world that cause significant economic losses specific to chrysanthemums. These are Chrysanthemum chlorotic mottle viroid (CChMVd) from the family Avsunviroidae and Chrysanthemum stunt viroid (CSVd) from the family Pospiviroidae. In this study, 56 collected from Adana, Mersin and Antalya in the Mediterranean Region. The chrysanthemum sample was scanned with the RT-PCR method and investigated in terms of contamination of 2 different viroids. As a result of the study, the presence of CSVd was determined in chrysanthemum plants. In the study, CChMVd, which is the quarantine agent, could not be detected in any of the collected isolates. CSVd agent was mechanically transferred to etrog citron and chrysanthemum plants. On these plants, signs of general stunting, small leaf size and mottling have developed.
\end{abstract}

Keywords: Chrysanthemum morifolium, CSVd, CChMVd, Viroid

ORCID ID (Yazar sirasına göre)

0000-0003-3455-8099, 0000-0003-2403-956X, 0000-0002-3274-5459, 0000-0002-5018-0850

\footnotetext{
Yayın Kuruluna Geliş Tarihi: 02.12.2021

Kabul Tarihi: 24.12.2021

${ }^{1}$ Çukurova Üniversitesi, Ziraat Fakültesi, Bitki Koruma Bölümü, Sarıçam/Adana

*E-posta:gborhan@gmail.com
} 


\section{Akdeniz Bölgesi Süs Bitkisi Yetiştiricilik Alanlarında Krizantem (Chrysanthemum morifolium Ramat.) Bitkilerinde Bulunan Viroidlerin Araştırılması}

\section{Giriş}

Süs bitkileri yetiştiriciliği çevre, bahçe ve şehir düzenlemeleri bakımından oldukça önemli görsellik bakımından tercih edilen bir tarım ürün gurubudur. Süs bitkileri kullanım amaçlarına göre; kesme çiçek, iç mekan (saksıli) süs bitkileri, dış mekan (tasarım) süs bitkileri ve çiçek soğanları olmak üzere 4 gruba ayrılmaktadır (Titiz ve ark., 2000). Dünya genelinde 2015 y1l itibari ile 1.752.081 hektar alanda süs bitkileri yetiştirilmektedir (Kazaz ve ark., 2016). 2019 y1lı süs bitkisi ekim alanları verilerine göre ülkemizde $52.477 .362 \mathrm{~m}^{2}$ lik alanda üretim yapılmaktadır. Bunun \%23.5'i kesme çiçek için kullanılırken \%3.7 si iç mekân (saksılı) süs bitkileri için kullanılmaktadır (TUIK, 2020). Anavatanı Japonya olan krizantem (Chrysanthemum morifolium Ramat.) bitkileri kesme ve saksılı süs bitkileri açısından oldukça önemli bir konuma sahiptir. Bunun yanı sira krizantem türleri peyzaj sektöründe kullanıldığı kadar endüstri sektöründe de kullanılan tarımsal bir üründür.

Artan üretim miktarları ile birlikte hastalık etmenleri ve zararlıların neden olduğu ürün kayıpları da artmaktadır. $\mathrm{Bu}$ hastalık etmenlerinden olan viroidler en küçük patojen olma özelliğindedir. "Viroid" terimi ilk olarak Thedor Diener tarafindan patates iğ yumru hastalığına neden olan etmenin virüs olmadığı ve protein kılıfı içermediği vurgulanmak için kullanılmıştır (Diener, 1971). Günümüzde yeni gelişmiş moleküler tanılama yöntemleri ile birçok bitki türünde enfektiyöz ve latent olarak bulunan viroid türü belirlenmiştir. Bitkilerde rapor edilmiş 8 cins içinde yer alan yaklaşı 32 tür viroid etmeni vardır (ICTV, 2020). Krizantem bitkileri üzerinde doğrudan etkili olan Chrysanthemum stunt viroid (CSVd) ve Chrysanthemum chlorotic mottle viroid (CChMVd)' süs bitkileri yetiştiriciliğinde bilinen en önemli etmenlerden iki tanesidir. $\mathrm{Bu}$ iki viroid dışında Citrus exocortis viroid (CEVd), Potato spindle tuber viroid PSTVd), Hop stund viroid (HSVd) etmenleri de krizantem bitkilerinde karışım halinde veya tek olarak bulunmakta ve enfeksiyon oluşturabilmektedir.
Ayrıca süs bitkilerinde bazı viroid enfeksiyonlarının latent olarak kaldığ 1 belirtilmektedir. Bununla birlikte latent enfeksiyonların dolaylı yoldan ticari bitki tür ve çeşitlerine etki edebileceği, bu çeşitlerin viroidle enfektelendiğinde ciddi ekonomik kayılar oluşturabileceği diğer ana bitkiler için inokulum kaynağı olabileceği bildirilmiştir (Verhoven ve ark., 2017).

2006 ve 2009 yılları arasında Türkiye de yapılan bir çalışmada patates, domates ve bazı süs bitkilerinde Pospiviroid familyasina ait viroid etmenleri tespit edilmiştir (Bostan ve ark. 2010). Çalışmada 154 krizantem bitkisinden 2'sinin CSVd ile bulaşık olduğu bulunmuştur. Bu çalışma ile araştırıcılar Türkiye'de CSVd'yi ilk kez rapor etmişler ancak sekans verilerini belirtmemişlerdir. Süs bitkileri yetiştiriciliği ve bunun içinde krizantem yetiştiriciliği son yıllarda gerek ülkemizde gerekse bölgemizde hızla artmaktadır. Ancak bu gruptaki bitkilerde bulunan viroid etmenleri üzerinde yapılan çalışmalar son derece sınırlıdır. Bu çalışmada krizantem bitkilerinde bulunan krizantem viroidlerinin Akdeniz Bölgesi'ndeki yetiştiricilik alanlarındaki durumu belirlenmeye çalışılmış ayrıca bu bitki grubunda bulunan viroidlerin moleküler ve biyolojik açıdan tanılanmaları gerçekleştirilmeye çalışılmıştır.

\section{Materyal ve Yöntem \\ Sörvey çalışmaları}

Çalışma Akdeniz Bölgesi'nin Adana, Mersin ve Antalya illerinde park ve bahçelerinde bulunan, süs bitkisi olarak üretilen ve satılan krizantem (Chrysanthemum morifolium Ramat.) bitkilerinde gerçekleştirilmiştir. Krizantem bitkilerinden yapraklarda sararma, bitkilerde bodurluk, yapraklarda beneklenme, çiçek yapisinda bozulma, petal yaprakta renk açılmaları, geç çiçeklenme gibi viroid kaynaklı hastalıkların karakteristik belirtilerini gösteren bitkilerden seçilmiştir. Ayrıca marketlerde satışta olan saksılı krizantem bitkileri, kesme çiçek olarak satılan bitkiler ve piyasada satışta olan ticari krizantem tohumları da materyal olarak kullanılmıştır. 


\section{Akdeniz Bölgesi Süs Bitkisi Yetiştiricilik Alanlarında Krizantem (Chrysanthemum morifolium Ramat.) Bitkilerinde Bulunan Viroidlerin Araştırılması}

Biyolojik indeksleme çalışmaları

CSVd etmeninin biyolojik indeksleme yöntemi ile tanısı sağlıklı doku kültüründen elde edilmiș krizantem bitkileri kullanılarak gerçekleştirilmiştir. Steril ortamda doku kültüründe yetiştirilmiş olan krizantem fideleri viyollere 1:1:1 oranındaki toprak, torf ve ponza taş1 karışımına aktarılarak çoğaltılmıştır. İndikatör bitkilerine mekanik olarak gövde çizme (Stem slash) yöntemi ile patojen bulaştırılması yapılmıştır. Toplanan krizantem örneklerinin yaprak, gövde ve çiçeklerinde CSVd, CCMVd etmenlerinin karakteristik olarak oluşturduğu bodurluk, yaprak küçülmesi, boğum aralarının kısalması, düzensiz çiçek gelișimi ve yapraklarda beneklenme simptomları gösteren bitkilerin TNA (Toplam nükleik asit) ekstraksiyonları yapılmıştır. RT-PCR çalışmaları sonucunda agar jel üzerinde pozitif bant geliştiren bitkilerden 3 adet örnek çalışma sonrasında pozitif bulunan bitkiler biyolojik indeksleme çalışmasına alınmıştır.

Sağlıklı krizantem bitkilerine mekanik olarak taşıma çalışmaları 8 yapraklı hale gelen krizantem bitkilerinin alt kısımdaki 4 yaprak koparılarak steril şırınga ucu ile gövdeye çizikler oluşturularak gerçekleştirilmiştir. Oluşturulan bu çizikler üzerine TKM $\quad(10 \mathrm{mM}$ Tris- $\mathrm{HCl} \mathrm{pH}$ 7.6,10 mM KCl, $10 \mathrm{mM} \mathrm{MgCl}_{2}$ ) çözeltisi ile $1 / 2$ oranında sulandırılmış TNA çözeltisi damlatılarak yaralardan bitki dokusuna geçiş sağlanmıştır. Çizme işleminden sonra gövdenin nemini koruması için parafinle sarılmıştır.

Çizelge 1: RT-PCR çalışmalarında kullanılan primer çiftleri

\begin{tabular}{|c|c|c|c|c|}
\hline $\begin{array}{l}\text { Viroid- } \\
\text { Primer }\end{array}$ & Sekans Dizilimi & $\begin{array}{l}\text { Bağlanma } \\
\text { Sicaklığ1 } \\
\left({ }^{\circ} \mathrm{C}\right)\end{array}$ & $\begin{array}{l}\text { Çoğaltılan } \\
\text { Bölge }\end{array}$ & \\
\hline CSVd-1H5 & 5' TTCTTGTAAAGCAGCAGGGT 3' & 55.3 & $55-36$ & \multirow[t]{2}{*}{ (Shiwaku et. al., 1996) } \\
\hline CSVd-1R & $\begin{array}{l}\text { 5' AAAGAAATGAGGCGAAGAAGTC } \\
\text { 3' }\end{array}$ & 56.5 & $56-77$ & \\
\hline CChMVd-2R & 5' AAAGGACCGGAACTGGATCT 3 & 57.3 & $217-236$ & \multirow[t]{2}{*}{ (Hosokawa et al. 2005) } \\
\hline CChMVd-2F & 5' ATCCATGACAGGATCGAAAC 3' & 55.3 & $29-48$ & \\
\hline CSVdF & 5-CAACTGAAGCTTCAACGCCTT-3 & 58 & \multirow[t]{2}{*}{253} & Hosokawa et al., 2004 \\
\hline CSVdR & 5-AGGATTACTCCTGTCTCGCA-3 & 59 & & Hosokawa et al., 2004 \\
\hline CSVd-2F & 5-CCAATCTTCTTTAGCACCGG-3 & 65 & \multirow[t]{2}{*}{221} & Hosokawa et al., 2004 \\
\hline CSVd-2R & 5-AGTGGGGTCCTAAGCCCCAA-3 & 55 & & Hosokawa et al., 2004 \\
\hline
\end{tabular}

\section{Moleküler çalışmalar \\ RT-PCR çalış̧maları}

Krizantem bitkilerinde bulunan viroidlerin tanılanması için CTAB (cetyltrimethylammonium bromide) tampon çözeltisi temelli TNA ekstraksiyonu gerçekleștirilmiștir. Ekstraksiyon çalıșmaları Murray ve Thompson (1980)'e göre modifiye edilerek uygulanmıştır. Elde edilen TNA'lardan komplementer DNA (cDNA) sentezi ve PCR çoğaltması yapılmıştır. PCR çalışmaları farklı primer çiftleri kullanarak klasik PCR (Barthe ve ark., 1998) ve Nested-PCR (Hosokawa ve ark., 2004) olarak iki farkl1 şekilde gerçekleştirilmiştir. RT-PCR çalışmalarında kullanılan primer çiftleri çizelge 1 'de belirtilmektedir. 


\section{Akdeniz Bölgesi Süs Bitkisi Yetiştiricilik Alanlarında Krizantem (Chrysanthemum morifolium Ramat.) Bitkilerinde Bulunan Viroidlerin Araştırılması}

\section{Elektroforez Çalıșmaları}

Elektroforez çalışmaları \%2'lik agar jel kullanılarak gerçekleştirilmiștir. Boyama işlemi etidyum bromür çözeltisi ile yapılmış ve jeller üzerindeki bantlar UV transilluminatör kullanılarak görüntülenmiştir.

\section{Jel Üzerinden Viroid Saflaştırılması}

Çoklu bant oluşturan örneklerden bir kısmı jel üzerinden kesilerek Roche Moleculer Biochemicals-High Pure PCR Product Prification Kit'i kullanılarak saflaştırma işlemi gerçekleştirilmiştir. $\mathrm{Bu}$ işlem firmanın önerdiği basamaklara göre yapılmıştır.

\section{Sekans analizi ve verilerin karşılaştırılması}

Jel görüntülemesi sonucunda viroid etmeninin varlığının saptandığı PCR ürünleri aynı koşullarda PCR uygulanarak 200 $\mu$ l hacminde çoğaltılmıştır. Çoğaltılan örneklerin saflaştırma ve nükleotid dizilimlerinin belirlenmesi amaciyla Adana ilinde bulunan MOLGENTEK firmasına gönderilmiştir. Sekanslama işlemi tamamlanan tüm örneklerin baz dizilimleri 'Finch TV', programı kullanılarak görüntülenip, mevcut baz dizilimleri NCBI (National Center for Biotechnology Information) veri tabanında "BLAST", yöntemiyle kayıtlı ilgili organizmalar ile karşılaştırılmıştır. Filogenetik analiz çalışmalarında da DNA dizileri ' MEGA X VERSION 10.0.2", (Molecular Evolutionary Genetics Analysis) programı kullanılarak "Neighbour Joining", metodu ile sınıflandırılmıştır (Kumar ve ark., 2018).

\section{Bulgular ve Tartışma}

Krizantem bitkilerinde viroid belirtilerine ilişkin sera ve satış yeri gözlemleri

Toplanan örneklerde, bitkilerinde bodurluk (Şekil 1a), yapraklarında sararma ve beneklenme (Şekil 1b), geç çiçeklenme (Şekil 1c), çiçek yapısında bozulma (Şekil 1d) ve petal yaprakta renk açılması gibi viroid ve virüsler için karakteristik olabilecek simptomlar gözlemlenmiştir. Belirlenen bu simptomlar viroid ve virüslerin oluşturabileceği genel simptomlar olup CSVd için özellikle bodurluk simptomları ve yaprak simptomları baz alınarak örnekler toplanmış ve çalıșma izolatları oluşturulmuştur. Arazi çalışmalarında krizantem bitkilerinde gözlenen simptomlar literatürde hastalikla ilgili belirtilen simptomlara benzerdir (Mehle ve ark., 2010, Chung ve ark., 2005). Krizantemlerde en fazla gözlenen simptom bodurluk simptomu olmuştur. $\mathrm{Bu}$ simptom bölgedeki her üç ilde gözlenmiştir. İkinci en yaygin simptom ise yapraklarda kloroz (sararma) ve geç çiçek açımı simptomlarıdır. Petal yapraklarda renk açılması, yapraklarda beneklenme ve çiçek yapısındaki bozulmalar Adana ve Antalya illerinde daha yaygin gözlenen simptom olmuştur.

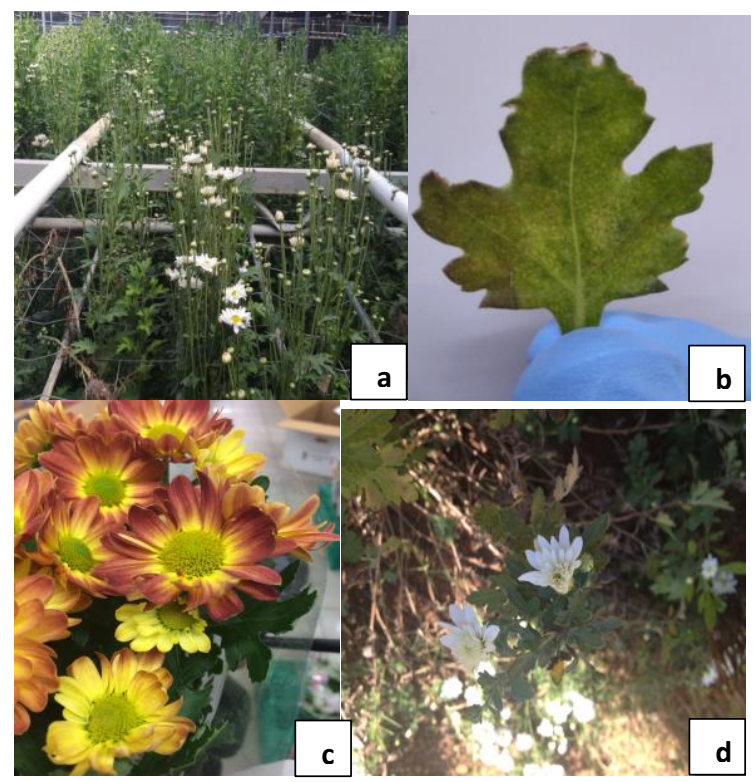

Şekil 1. a- Kesme krizantem yetiştiriciliği yapılan bir serada çiçeklerde geç açılma ve bitki lerde bodurluk görüntüsü (Tarsus) b- krizantem yapraklarında meydana gelen klorotik beneklenme simptomları (Adana) c- saksılarda yetiştirilen krizantemlerdeki çiçek yapısındaki renk kırılmaları ve geç çiçeklenme (Adana) d- petal yaprak gelişimini tam tamamlamamış çiçeklerin simptomu (Adana)

\section{Krizantem bitkilerinde tespit edilen viroidlerin biyolojik indeksleme çalışmalarına ait bulgular}

Doku kültüründen elde edilmiş krizantem bitkilerinin indikatör bitki olarak kullanıldığ 1 bu çalışmada simptomlar inokulasyon işlemlerinden yaklaşık 6 hafta sonra gözlenmeye başlamıştır. Sağlıklı krizantem bitkilerinde ilk belirtiler, bodurlaşma, boğum aralarında kısalma ve yaprak boyutlarında küçülmeler hafif 


\title{
Akdeniz Bölgesi Süs Bitkisi Yetiştiricilik Alanlarında Krizantem (Chrysanthemum morifolium Ramat.) Bitkilerinde Bulunan Viroidlerin Araştırılması
}

klorozlar olarak gözlemlenmiştir (Çizelge 2). kaldığı ve tam açılma göstermediği İlerleyen dönem içinde çiçek yapısında da farklılaşmalar gözlenmiş olup çiçeklerin küçük

\author{
belirlenmiştir.
}

Çizelge 2: İndikatör bitkilerde gözlemlenen belirtiler (B: Bodurlaşma, BAK: Boğum arası kısalma, KY: Küçülmüş yaprak, YHK: Yapraklarda hafif kloroz, KÇ: Küçük çiçek yapısı, YK: Yapraklarda kıvırcıklaşma)

\begin{tabular}{|l|l|l|l|l|l|l|}
\hline \multirow{2}{*}{\multicolumn{1}{|c|}{ İzolatlar }} & \multirow{2}{*}{ İndikatör bitki } & \multicolumn{5}{c|}{ Gözlemlenen belirtiler } \\
\cline { 3 - 8 } & & KY & B $\backslash$ BAK & YHK & KÇ & YK \\
\hline KriAd-27 & Krizantem & + & + & + & & - \\
\hline KriTa-4 & Krizantem & & + & & & - \\
\hline KriAd-38 & Krizantem & + & + & + & - & - \\
\hline Kontrol - & Krizantem & - & - & - & - & - \\
\hline KriTa-4 & Etrog citron & - & - & - & - & + \\
\hline KriAd-27 & Etrog citron & - & - & - & - & + \\
\hline KriAd-38 & Etrog citron & - & - & - & - & + \\
\hline Kontrol + & Etrog citron & - & - & - & - & + \\
\hline Kontrol - & Etrog citron & - & - & - & - & - \\
\hline
\end{tabular}

Niblett ve ark, (1980) yürütmüş oldukları çalışmada CSVd etmeninin inokulasyonunun gerçekleştirildiği bitkilerde bodurluk, yapraklarda klorotik lekeler oluştuğunu bildirmişlerdir. $\quad \mathrm{CEVd}$ etmeninin inokulasyonunun yapılmış olduğu bitkilerde ise bodurluk, yapraklarda bükülme gibi belirtileri gözlemlediklerini bildirmişlerdir. Biyolojik indeksleme çalışmasında elde edilen bulgular bu çalışmayla uyumludur ve sağlıklı krizantem bitkilerinde benzer sonuçlar elde edilmiştir. Ayrıca Duran-Vila ve ark. (1988) yapmış oldukları çalışmada etrog bitkilerinin bu iki etmene karşı hassasiyet gösterdiklerini ve krizantem bitkilerinde de CEVd'in bodurluk belirtisi geliştirdiğini, HSVd'nin ise çok hafif belirtiler oluşturduğunu bildirmişlerdir.

\section{Moleküler çalışmalar ile ilgili bulgular ve tartışma \\ RT-PCR çalıșmaları ile ilgili bulgular}

Çalışmanın konusunu olușturan CSVd'nin bölgemizdeki krizantem bitkilerinde varlığını ve yoğunluğunu araştırmak amacıyla yürütülen bu çalıșmada toplam 56 adet izolat RT-PCR ile incelenmiştir. Çalışmanın ilk aşamasında CSVd-
1H5 ve CSVd-1R primer çifti kullanılmıştır. Yapılan analiz sonucunda jel üzerinde örneklerde 2'li ve 3'lü bantlar elde edilmiştir. İncelenen 56 adet örneğin 15 tanesinde çoklu bant elde edilmiștir. RT-PCR çalışmasında 9 adet örneğin tamamı 3'lü bant, 6 örnek ise 2'li bant oluşturmuştur (Şekil 2). Daha sonra Pospil1R ve Pospil2F evrensel primerleri kullanılmış ancak bu iki primer çifti kullanıldığında herhangi bir bant oluşumuna rastlanılmamıştır.

$\mathrm{Bu}$ aşamada Roche Moleculer BiochemicalsHigh Pure PCR Product Purification Kit'i kullanılarak çoklu bantlardan 2 tanesi (KriTa-4, KriAd-27) çoğaltılarak jel üzerinden kesim işlemi gerçekleştirilmiş ve bantlar birbirinden ayrılarak saflaştırılmıştır. CSVd'ni belirlemek için primer çiftleri CSVd1R-CSVd1F ve CSVd2R-CSVd2F kullanılarak nested-PCR çalıșmasına gidilmiștir. Yapılan ilk aşama RTPCR ürünlerinin jel üzerinde 253 bç seviyesinde CSVd'ye ait bantlar elde edilmiştir (Şekil 2b). 


\section{Akdeniz Bölgesi Süs Bitkisi Yetiştiricilik Alanlarında Krizantem (Chrysanthemum morifolium Ramat.) Bitkilerinde Bulunan Viroidlerin Araştırılması}
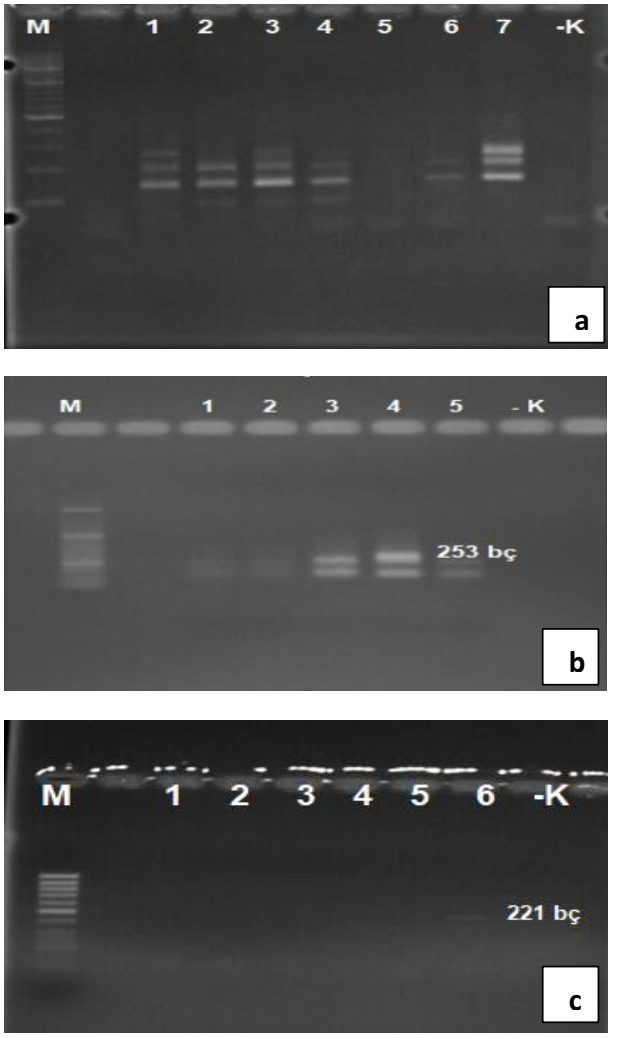

Şekil 2. a-CSVd-1H5-1R primerlerinin kullanıldığ çoklu viroid bantlarının jel görüntüsü b- Nested-PCR çalışmalarının ilk aşamasında CSVd1F/CSVd1R primerlerinden alınan jel görüntüsü. c- Nested-PCR çalışmalarının ikinci aşamasında CSVd2F/CSVd2R primerleri kullanılarak pozitif olarak belirlenen KriAd-27 izolatının agar jelde 221 bç'i görüntüsü.

Nested-PCR'in 2. PCR aşamasında ise sadece bir örnekte 221 bç uzunluğundaki bant görülmüştür (Şekil 2c). Diğer örneklerde herhangi bir bant gözlemlenmemiştir. CSVd için toplam 2 adet izolattan pozitif sonuç alınmıştır. $\mathrm{Bu}$ sayı etmen açısından oldukça düşük bir rakam olarak ortaya çıkmıştır. Sonuç olarak bu çalışmada incelenen krizantem bitkilerinin CSVd açısından oldukça düşük bir bulaşıklılık oranına sahip olduğu belirlenmiştir. Elde edilen bu ürün sekans çalışmasına gönderilmek amacıyla aynı koşullarda tekrar çoğaltılmıştır.

Dünya'da CSVd'nin yaygınlık durumuna baktığımızda etmen ilk kez virüs olarak ABD'de 1945 yılında bildirilmiştir (Dimock, 1947). Daha sonra Kanada 'da 1950 yilında bildirilerek buradan dünyanın her tarafina dağıldığı belirtilmiştir (Lawson, 1987). Etmen tüm Avrupa ülkelerinde karantina etmeni olmas1 nedeniyle bu ülkelerde yaygınlığa konusunda fazla bilgi olmamakla birlikte etmenin İtalya'da simptom göstermeyen krizantem bitkilerinde bulunduğu buna ek olarak Argyranthemum frutescens bitkilerinde de simptom oluşturduğu bildirilmiştir (Torchetti ve ark., 2012).

\section{Etmen Hindistan'da \%28.3 (Adkar-} Prushhothama ve ark., 2017) ve Brezilya'da \%58 (Gobatto ve ark., 2014) oranlarında oldukça yaygın bir şekilde bulunmaktadır. Çinli araştırmacıların yapmış olduğu çalışmada ise etmenin yine Avrupa ülkelerinde olduğu gibi çok yaygın bulunmadığı CSVd'nin \%2.9 oranında bulunduğu bildirilmiştir (Zhao ve ark., 2015).

Ülkemizde krizantem bitkilerinde CSVd etmenini ilk kez Bostan ve ark. (2004) bildirmişlerdir. Yapılan çalışmada Pospiviroidae familyası üyelerinin korunmuş bölgelerinin tanılanmasında kullanılan primer çifti kullanılmış ve 154 krizantem bitkisinin 2'sinde CSVd etmenin agar jel üzerindeki 199 baz uzunluğundaki bant görüntüsünü tespit etmişlerdir (Bostan ve ark., 2010). Bu çalışmada da benzer şekilde CSVd'nin bulunma oranını oldukça düşük oranda bulunmuştur. Etmen ülkemizde yaygın olarak bulunmadığ çalışma ile de ortaya konmuştur. Ticari olarak satılan krizantem tohumlarının CSVd etmenini açısından testlemek amacıyla RT-PCR yöntemi kullanılan bu çalışmada 10 farklı markaya ait olan krizantem tohum örneklerinin TNA ekstraksiyonları yapıld1ktan sonra random primer ile cDNA sentezleri yapılmıştır. RT-PCR çalışmalarında CSVd etmenini tanıyabilen CSVd-2H1 ve CSVd-1R primer çifti kullanılmıştır.

Ancak agar jelde yapılan yürütme sonucunda CSVd'ye ait herhangi bir bant oluşunu gözlenmemiştir. $\mathrm{Bu}$ nedenle tüm tohum örneklerinin bu etmen açısından negatif olduğu ve tohumların temiz olduğu düşünülmektedir.

Krizantem bitkilerinde bulunan ve ülkemizde karantina etmeni olarak EPPO'nun A2 listesinde yer alan CChMVd etmenini araştırdığımız çalışmada CChMVd-2R ve CChMVd-2F 


\section{Akdeniz Bölgesi Süs Bitkisi Yetiştiricilik Alanlarında Krizantem (Chrysanthemum morifolium Ramat.) Bitkilerinde Bulunan Viroidlerin Araştırılması}

\begin{abstract}
primerleri kullanılmıştır. RT-PCR çalışmalarının sonucunda incelenen tüm izolatlarda agar jelde herhangi bir bant oluşumu gözlenmemiştir. Çalışmada moleküler bazda herhangi bir bulguya rastlanılmamasi bu etmenin toplanan örneklerde var olmadığını ortaya koymaktadır. Ancak simptomolojik açıdan benzer simptomların besin elementi noksanlığından veya krizantemde bulunabilecek diğer viral hastalıkların neden olabileceği düşünülmektedir. Nitekim krizantemde bulunan Tomato spotted wild virüs etmeninin yapraklarda klorotik beneklenmelere neden olabilecek ortak simptomlar olduğu belirtilmektedir (Matteoni ve Allen, 1989).
\end{abstract}

Elde edilen baz dizilimleri NCBI (National Center for Biotechnology Information) veritabanı kullanılarak bu bankada kayıtlı organizmalar ile karșılaştırılmıștır. Filogenetik analiz çalışmasında ise DNA dizileri Mega X (Molecular Evolutionary Genetics Analysis) programı kullanılarak gerçekleştirilmiş ve "Neighbour Joining" metodu ile sınıflandırılmıştır. Genom dizileri belirlenen KriAd-27 izolatının nt uzunluğu 244 nt olarak elde edilmiştir. Elde edilen bu izolatın BLAST analizi sonucunda CSVd'i NCBI gen bankasında kayıtlı olan viroidlerle \%96-\%98 oranında benzerlik gösterdiği belirlenmiştir (Şekil 3).

NCBI gen bankası kayıtlarında yer alan Hindistan izolat1 Adana ilinden toplanan krizantem izolatı ile \%99.4 benzerlik gösterirken Avusturya izolatı ile \%98, Çin izolatı ile ise $\% 98$ oranında benzerlik göstermiştir. Mega $X$ programı kullanılarak Şekil 3'de oluşturulan filogenetik ağaçta bu çalışmada elde ettiğimiz Adana izolatının KriAd-27 Hindistan (KP262537) ve Avusturya (JF414238) izolatlarıyla benzer olduğunu Çin izolatının (FJ031232) ise bunlara yakın alt bir kümede yer aldı ğını ortaya konmuştur. (Şekil 3).

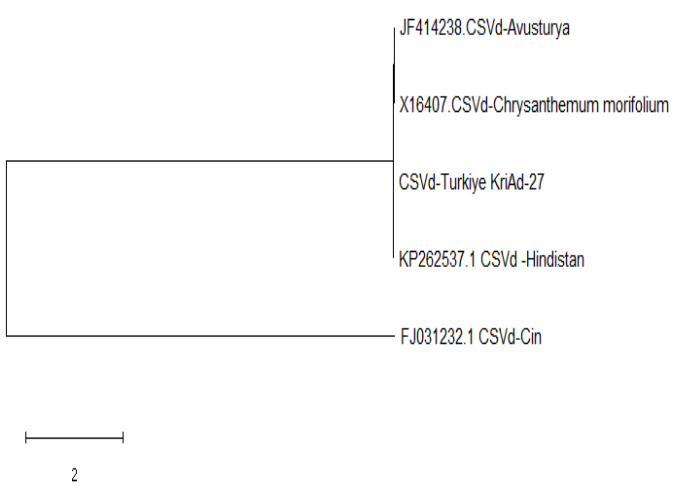

Şekil 3: Adana ilinden elde edilen KriAd-27 izolatının soy ağacı.

\section{Kaynaklar}

Adkar-Purushothama, C.R., Chennappa, G., Poornachandra Rao, K., Sreenivasa, M.Y., Maheshwar, P.K., Nagendra Prasad, M.N., Sano, T. 2017. Molecular diversity among viroids infecting chrysanthemum in India. Virus Genes, 53, 636-642.

Barthe G.A., Ceccardi T.L., Manjunath K.L., Derrick K.S., 1998. Citrus psorosis virus: nucleotide sequencing of the coat protein gene and detection by hybridization and RT-PCR. Journal of General Virology, 79 (Pt 6), 1531-1537.

Bostan, H.; Nie, X.; Singh, R.P., 2004. An RTPCR primer pair for the detection of Pospiviroid and its application in surveying ornamental plants for viroids. J. Virol. Methods, 116, 189-193.

Bostan, H., Gazel, M., Elibüyük, I.O., Çağlayan, K., 2010. Occurrence of pospiviroid in potato, tomato and ornamental plants in Turkey. African Journal of Biotechnology, 9: 2613-2617.

Chung, B. N., Lim , J. H., Choi, S. Y., Kim, J. S., Lee, E. J., 2005. Occurrence of Chrysanthemum stunt viroid in Chrysanthemum in Korea. The Plant Pathology Journal, 21(4), 377-382. 


\section{Akdeniz Bölgesi Süs Bitkisi Yetiştiricilik Alanlarında Krizantem (Chrysanthemum morifolium Ramat.) Bitkilerinde Bulunan Viroidlerin Araştırılması}

Diener, T., 1971. Potato spindle tuber "virus", IV. A replicating low-molekular weight RNA, Virology 45, 411.

Dimock, A.W., 1947. Chrysanthemum stunt. NY State Flower Growers Bull., 26, 2. NEW YORK STATE FLOWER GROWERS INCORPORATED, BULLETIN \# 26.

Duran-Vila, N., Pina, J.A., Ballesta, J.F., Juarez, J., Roistacher, C.N., Rivera-Bustamenta, R. And Semancik, J.S., 1988. The citrus exocortis disease: A complex of viroidRNAs page 152-165 in:. Proc. 10 th Intern. Org. Citrus Virologist (IOCV) Conf., Riverside-California, U.S.A.

Gobatto, D., Chaves, A.L.R., Harakava, R., Marque, J.M., Daròs, J.A., Eiras, M., 2014. Chrysanthemum stunt viroid in Brazil: Survey, identification, biological and molecular characterization and detection methods. J. Plant Pathol., 96, 111-119.

Hosokawa, M., Ueda, E., Ohishi, K., 2004. Chrysanthemum stunt viroid disturbs the photoperiodic response for flowering of chrysanthemum plants. Planta 220, 64 70.

Hosokawa, M., Y. Matsushita, K. Ohishi and S. Yazawa. 2005. Detection of Chrysanthemum chlorotic mottle viroidlike RNA in Japanese chrysanthemum. J. Japan. Soc. Hort. Sci. 74: 386-391.

ICTV,2020.https://talk.ictvonline.org/taxonomy

Kazaz, S., 2016. Dünya Süs Bitkileri Sektöründe Ürün Deseni, Sosyo Ekonomik ve Teknoloji Alanında Yaşanan Gelişmeler ile Türkiye'nin Gelecek Vizyonu. 6. Süs Bitkileri Kongresi bildiriler kitabı. Syf:313

Kumar S., Stecher G., Li M., Knyaz C., and Tamura K., 2018. MEGA X: Molecular Evolutionary Genetics Analysis across Computing Platforms. Mol. Biol. Evol. 35(6):1547-1549.

Lawson, R.H., 1987. Chrysanthemum stunt. Pages 247-259 in: The viroids. T.O.
Diener, ed. Plenum Press: New York and London.

Matteoni J.A., Allen W.R., 1989. Symptomatology of tomato spotted wilt virus infection in florist's chrysanthemum. Canadian Journal of plant pathology.,11:373-380

Murray M.G., Thompson W.F., 1980. Rapid isolation of high moleculer weight plant DNA. Nücleic Acids Res. Oct 10; 8 (19) 4321-4325.

Mehle, N., Seljak, G., Verhoeven, J.Th.L., Jansen C.C.C., Prezelj, N., Ravnikar, M., 2010. Chrysanthemum stunt viroid newly reported in Slovenia. Plant Pathol., 59, 1159-1159.

Niblett, C.L., Dickson, E., Horst, K.K., Romaine, C.P., 1980. Additional hosts and an efficient purification procedure for four viroids. Phytopathology 70, 610-615.

Shiwak K., Iwai, T., Yamamoto, Y., 1996. Cloning and nucleotide sequence of Chrysanthemum stunt viroid. Hyogo Pre Agric Inst (Agriculture) 44:1-4.

Titiz, S., Çakıroğlu, N., Biriş̧̧i Yıldırım, T., Çakmak, S., 2000. Süs bitkileri üretim ve ticaretindeki gelişmeler. V. Türkiye Ziraat Mühendisliği Teknik Kongresi, (17-21 Ocak 2000), Cilt II, 709-740, Ankara.

Torchetti, E.M., Navarro, B., Trisciuzzi, V.N., Nuccitelli, L., Silletti, M.R., Di Serio, F., 2012. First report of Chrysanthemum stunt viroid in Argyranthemum frutescens in Italy. J.Plant Pathol. 94, 451-454.

TÜíK,

2020.

https://biruni.tuik.gov.tr/bitkiselapp/bitkis el.zul. (Erişim tarihi:13.09.2021)

Verhoeven, J.T.J.; Hammond, R.W.; Stancanelli, G., 2017. Economic significance of viroids in ornamental crops. In Viroids and Satellites; Hadidi, A., Flores, R., Randles, J.W., Palukaitis, P., Eds.; Elsevier: London, UK, 27-38, ISBN 9780128014981. 
Akdeniz Bölgesi Süs Bitkisi Yetiştiricilik Alanlarında Krizantem (Chrysanthemum morifolium Ramat.) Bitkilerinde Bulunan Viroidlerin Araştırılması

Zhao, X., Liu, X., Ge, B., 2015. A multiplex RTPCR for simultaneous detection and identification of five viruses and two viroids infecting chrysanthemum. Arch. Virol. 160, 1145-1152. 
Akdeniz Bölgesi Süs Bitkisi Yetiştiricilik Alanlarında Krizantem (Chrysanthemum morifolium Ramat.) Bitkilerinde Bulunan Viroidlerin Araştırılması 